\title{
Protein and amino acid nutrition of the pig
}

By M. F. FulLeR, Rowett Research Institute, Bucksburn, Aberdeen $A B 2{ }_{9} S B$

Pig production may be variously described as the squandering of valuable food resources to satisfy consumer demand for an enjoyable luxury - an industry no different from numerous others in the consumer economy-or as a means of converting to a high quality food agricultural products for which no real alternative use exists. Between these two extremes, shades of opinion reflect circumstances, and the value placed upon resources. But whatever one's view of pig production, the pig's efficiency as a transformer of energy and protein is of central importance. My purpose in this paper is to take a prospective look at the use of protein and amino acids in pig nutrition, to identify sources of inefficiency and to suggest possible routes to improvement in the future.

Table I illustrates the inputs of food protein and energy typical of commercial pig production. Several points emerge from this simple overview. First, only about one-third of the protein used in pig production is deposited as body protein, and less than a fifth is recovered in the edible parts of the carcase. Secondly, the food energy required to produce $\mathrm{I} \mathrm{kg}$ body protein is over $300 \mathrm{MJ}$, or closer to $600 \mathrm{MJ}$ if only the edible protein is considered. By comparison the microbial production of protein in industrial fermentations typically requires only $5^{\circ} \mathrm{MJ}$ of carbohydrate energy $/ \mathrm{kg}$ of protein produced (Mateles, I979).

There are clearly many factors which influence these efficiencies. Aspects of general husbandry such as disease control, reduction of mortality, avoidance of feed spillage and so on will give improvements. Although, as seen in Table I, the breeding stock account for only a small fraction of the total feed input, improvements in their productivity have a detectable influence on the over-all efficiency of food use (Large, 1973, 1976).

Table I. Use of protein and energy to produce meat protein

$\begin{array}{lcc} & \begin{array}{c}\text { Protein } \\ (\mathbf{k g})\end{array} & \begin{array}{c}\text { Energy } \\ (\mathrm{MJ})\end{array} \\ \text { Eaten by I sow in I year } & 140 & 15400 \\ \text { Eaten by 20 pigs growing to 90 kg } & 690 & 69300 \\ \text { Total } & 83^{\circ} & 84700 \\ \text { Gained by sow } & 3 & \\ \text { Gained by pigs } & 25^{\circ} & \\ \text { Total } & 253 & \\ \text { To produce I kg protein: } & & \\ \quad \text { in whole animal } & 3 \cdot 3 & 335 \\ \text { in edible parts } & 5 \cdot 7 & 577\end{array}$

$0029-665^{1} / 80 / 3923-3807$ Sor.00 $c$ The Nutrition Society 
Table 2. Typical protein utilization $(\mathrm{g} / \mathrm{d})$ by a growing pig of $60 \mathrm{~kg}$

$\begin{array}{lr}\text { Dietary protein } & 420 \\ \text { Lost in faeces } & 60 \\ \text { Used for maintenance } & 34 \\ \text { Lost as skin and hair } & 3 \\ \text { Amino acid degradation: } & \\ \text { due to imperfect balance } & 97 \\ \text { due to accelerated oxidation } & 96 \\ \text { Body protein accretion } & 130\end{array}$

Table 2 shows the sources of loss in the utilization of protein by a typical growing pig of $60 \mathrm{~kg}$, the porcine equivalent of the medical world's Mr Average, the $70 \mathrm{~kg}$ Caucasian male. Of the $420 \mathrm{~g}$ of protein that his daily ration supplies, only $130 \mathrm{~g}$ is retained. The loss of the remaining $290 \mathrm{~g}$ may be attributed to four major causes. (I) Losses in digestion. (2) Amino acid oxidation due to an imperfect amino acid balance. (3) Maintenance requirements. (4) Amino acid oxidation: failure to utilize fully even a balanced protein when given at a rate sufficient to allow rapid growth.

\section{Losses in digestion}

The proportion of the protein intake lost in the faeces ranges from less than $5 \%$ for such sources as milk products, fish and isolated vegetable proteins to $25 \%$ or more for those plant proteins that are associated with the fibrous material of the plant cell walls.

In the past, losses of $\mathrm{N}$ in faeces and urine have been considered as completely discrete entities, but in recent years a picture of digestion has emerged to suggest otherwise. It has been known for some time that a large fraction of faecal $\mathrm{N}$ consists not of undigested feed proteins but of microbial protein, its amount depending on the quantity and nature of the carbohydrate reaching the large intestine (Mason \& Palmer, 1973). When large amounts of undigested feed protein reach the lower digestive tract together with only small amounts of fermentable carbohydrate, bacterial degradation of the protein liberates ammonia which is absorbed into the mesenteric blood, to be eventually excreted in the urine. Conversely, when much fermentable carbohydrate, but with little protein, enters the large intestine and microbial protein synthesis is limited by the $\mathrm{N}$ supply, nitrogenous material from the host's blood may be taken up by the hind-gut to emerge as microbial protein in the faeces. So urine and faeces may be to some extent complementary to each other, functioning as alternative routes of $\mathrm{N}$ excretion.

\section{Losses due to imperfect amino acid balance}

It is less than 30 years since Mertz et al. (1952) showed that for normal growth the young pig requires in its diet the same ten essential amino acids as the growing rat: threonine, valine, isoleucine, leucine, phenylalanine, tryptophan, 
methionine, arginine, histidine and lysine. Since that time, a great number of experiments have been made to estimate the amounts of these essential amino acids the pig requires. Early approaches were based on the analysis of proteins which feeding trials had shown to be of high quality (Becker et al. I954). Although providing somewhat circumstantial evidence this approach can give useful results when proteins with biological values close to $I \cdot O$ are used to assess amino acid requirements, and it is still used in the absence of more critical information (Agricultural Research Council, 1967; Rerat \& Lougnon, 1968). It is tempting to assume that a protein with a BV of $1 \cdot 0$, which by definition is fully utilized for the combined processes of maintenance and tissue growth, necessarily supplies the animal with amino acids in a uniquely ideal pattern. It seems equally possible that a protein such as whole egg, which has a BV of $\mathbf{r} \cdot 0$, could include a moderate excess of one or more essential amino acids (those which are tolerated in excess) which could be used for the synthesis of an isonitrogenous quantity of non-essential amino acids. In this connexion, we have observed (Fuller et al. 1979) that in a mixture of cereal protein and amino acids which had a BV of 0.93 for growing pigs, essential amino acids accounted for only $39 \%$ of the protein, compared with $63 \%$ in egg protein. Kofranyi's (1973) experiments on the dilution of egg protein with diammonium citrate applies only to maintenance and there are no comparable results for growth.

Block \& Bolling (1944) observed that proteins of high nutritive value resemble in their amino acid make-up the tissues of the animals eating them. This led to the concept (Mitchell, 1950) that an animal's amino acid requirements are determined primarily by the amount and amino acid composition of the proteins being synthesized. It is self-evident that to form a given quantity of protein an animal must obtain from its food at least as much of each amino acid as that protein contains, and this forms a logical starting point to any factorial assessment of amino acid requirements. How much more of each is needed depends on how efficiently each is utilized, and this will be considered later.

In addition to these net requirements for growth, animals require protein for maintenance. Mitchell (1950) emphasized the differences in amino acid composition between the keratins, with their high content of cystine and arginine, collagen of connective tissue, devoid of tryptophan, and the contractile proteins of muscle, rich in lysine. Mitchell argued that the amino acids needed for keratin synthesis would dominate maintenance needs, whereas for growth, the animal's needs would reflect the pattern of amino acids in muscle, viscera and connective tissue. The dissimilarity between the amino acid patterns required for maintenance and for growth have been demonstrated clearly by Said \& Hegsted (I970) and Dreyer (1975).

Certainly, for the growing animal, for which maintenance accounts for only a small part of total protein needs, good correlations were obtained between tissue amino acid composition and contemporary estimates of requirements for the rat (Mitchell, 1950), chick (Fisher \& Scott, 1954) and the pig (Williams et al. 1954). Mitchell suggested that if the pattern of amino acids required could be predicted 
by knowing the composition of the proteins being formed, then it would only be necessary to estimate, by empirical experiment, the requirement for one amino acid (he suggested lysine), the requirements for all others being obtained by reference to this pattern.

The attention paid in these studies of the 1950 s to the balance of amino acids kept the concepts of amino acid requirement and of protein quality closely related, but during the subsequent 20 years they seemed to become separated (witness, for example, ARC (1967)) and only recently have they been more evidently brought together again. There seem to be two reasons for this. First, it became evident to those interested in formulating practical diets for pigs that the problem of meeting protein requirements centred around the outstanding deficiencies of the cereal staples in lysine. It was found that in adding to cereals sufficient of any of the common protein sources to meet the animal's lysine requirements, the requirement of every other amino acid was more than adequately satisfied. Secondly, the measurement of protein quality was usually made with small animals given diets containing 8 or $10 \%$ of the protein, whereas the interest of animal scientists was in large farm animals given diets that would produce rates of growth equal or close to the maximum.

For these reasons most estimates of amino acid requirements have been made from empirical dose-response relationships, but whereas Mitchell's original suggestion was to maintain an ideal balance between amino acids at each level of the test amino acid (in other words to make graded additions of an ideally balanced protein) most experimenters have measured the response to one amino acid whilst keeping the levels of all others constant.

\section{Amino acid oxidation}

When given in small quantities, but with adequate amounts of non-protein energy, well-balanced proteins can be completely utilized for the combined processes of maintenance and the low rate of growth that such limited quantities of protein permit. These are the conditions under which the BV is measured. As the dietary concentration of a protein, of whatever $\mathrm{BV}$, is increased, the efficiency with which it is used falls, and when sufficient is given to allow rapid growth it may be used only half as efficiently as under the conditions of measuring its BV. It is the reasons for this effect and the underlying control of amino acid oxidation in these circumstances that $I$ wish to discuss in this section. The discussion resolves into teleological answers to the question 'why?' and mechanistic answers to the question 'how?'.

Control of amino acid oxidation is an evident necessity to an animal which cannot, continuously and precisely, match its food supply to its needs. First, it allows an animal to dispose of otherwise intoxicating accumulations of imbalancing amino acids. Secondly, it allows it to derive energy from amino acids from either the diet or body tissues when other sources of energy fail. Thirdly, it allows the animal to regulate the relative rates of protein and fat accretion so as to maintain an appropriate balance between lean tissue growth and the fat stores 
Vol. 39

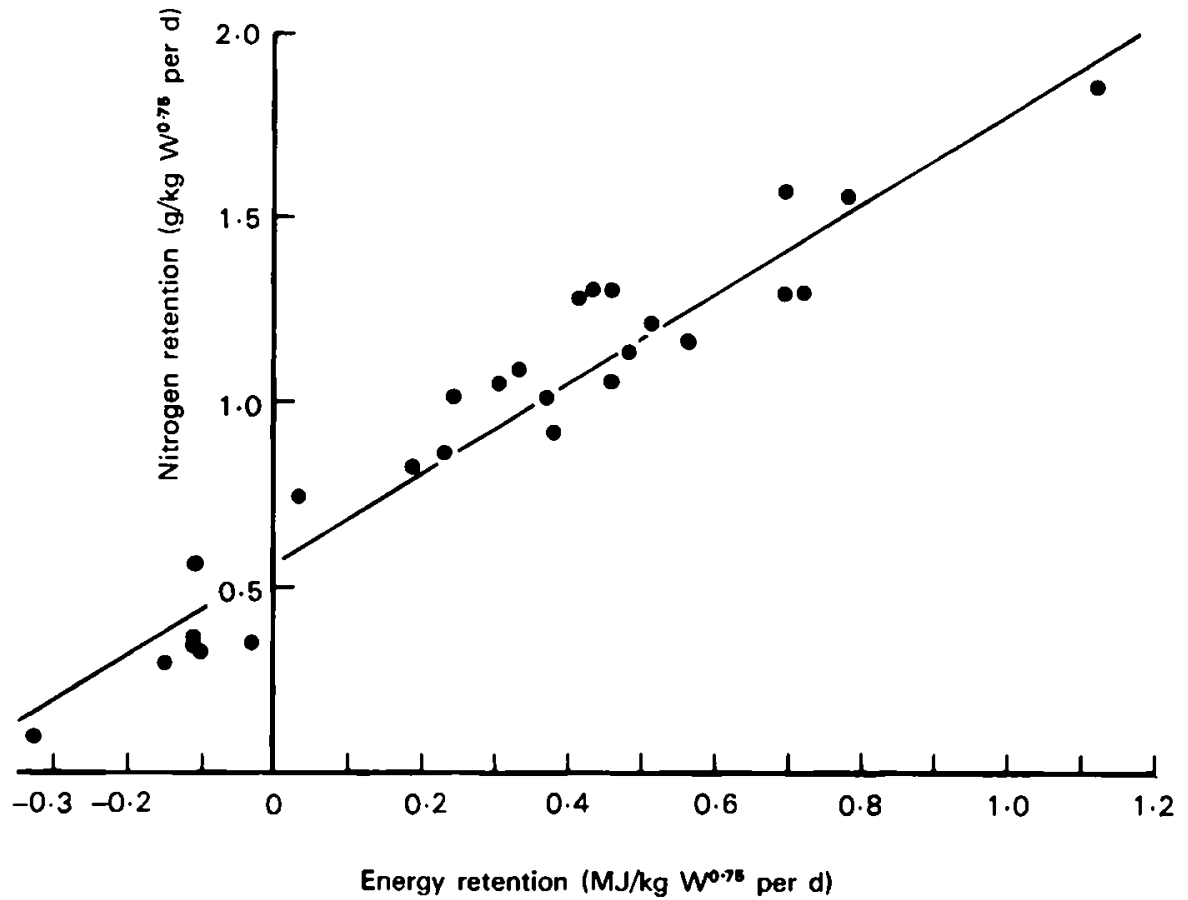

Fig. I. The relationship between the rates of nitrogen retention and of energy retention in pigs of $30 \mathrm{~kg}$ given various amounts of food. (Fuller et al. $1976 b$ ).

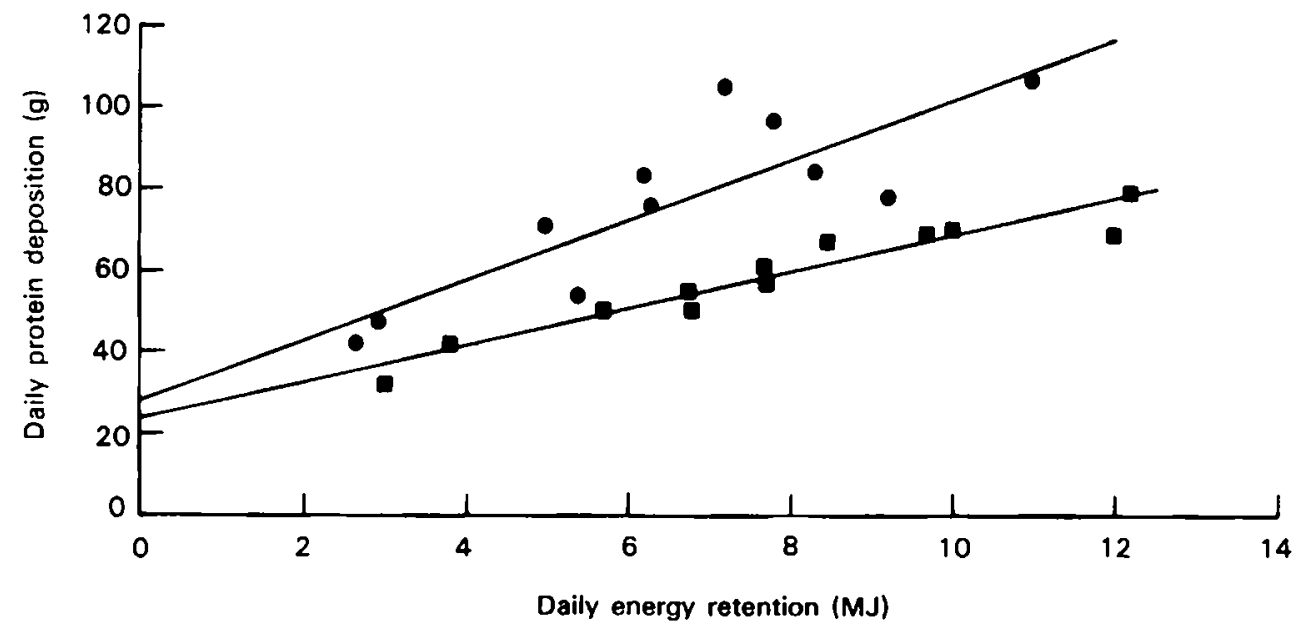

Fig. 2. The influence of dietary protein concentration ( $\mathrm{g} / \mathrm{kg} \mathrm{diet)}$ on the relationship between the rate of protein deposition and the rate of energy retention. (D), 130; $y=24+6.7 x ;(0), 220$; $y=29+11 \cdot 0 x$. Houseman (1972). 
which may be required to maintain that tissue if food becomes scarce. This balance, between lean tissue and what Fowler (1976) has called the 'target fat mass' is not a constant proportionality, but springs from the characteristic relationship between the rate of protein deposition and the rate of energy retention, an example of which is given in Fig. x. At energy equilibrium, growing animals, at least in the short term, retain protein at a considerable rate (provided the diet is not severely limited in protein) which is offset by an isoenergetic loss of fat. With increasing food supply, the rate of energy retention rises but an increasing proportion of it is in the form of fat. The relationship is not immutably fixed. Fig. 2 shows how it is altered by changing the protein content of the diet. Presumably the faster growth made possible by the greater protein intake is more likely to confer an advantage than the lower rate of growth coupled with greater energy reserves.

How is this control of protein metabolism achieved? First, the excess of an individual imbalancing amino acid is degraded by specific enzymes induced by the accumulating concentrations of their substrates. With an increasing supply of a balanced protein, the degradative pathway of every amino acid is stimulated, and an increasing proportion of the supply is degraded. This regulatory system is modulated by the supply of energy as carbohydrate and fat, hence the dependence of the protein/fat relationship of Fig. 3 on dietary protein concentration.

There seem to be three ways in which carbohydrate and fat exert their effect on protein utilization. The first is simply that protein synthesis requires energy; amino acid degradation releases it. Indeed, protein accretion is associated with a considerable energy expenditure, as will be discussed later. The second point at which non-protein energy exerts its influence on protein utilization is at their convergence in the tricarboxylic acid cycle. A large flux of a TCA intermediate arising from carbohydrate or fat dissimilation inhibits the production of that intermediate from amino acid by end-product feedback. There is also evidence of direct effects of glucose and fatty acids on urea synthesis (Nakano \& Ashida, 1974).

Thirdly, carbohydrate and perhaps fat, can affect protein utilization through the actions of hormones responsive to them. The anabolic effects of insulin, which lie both in enhancing synthesis and suppressing breakdown. (Jefferson et al. 1974; Fulks et al. I975) and amino acid oxidation (Nakano \& Ashida, 1975), are responsive to dietary carbohydrate. What comparable mechanism exists for fats is not known.

Of these three aspects of control, only the first involves an expenditure of energy; control by the second and third means is exerted solely by the metabolites (which may then be oxidized or stored according to need) or indirectly through their effects on hormone action.

\section{Energy cost of protein utilization}

The basic mechanism of protein synthesis requires the hydrolysis of at least four high-energy phosphate bonds for each amino acid incorporated. With an allowance for the cost of synthesizing the several species of nucleic acids also involved, it is 


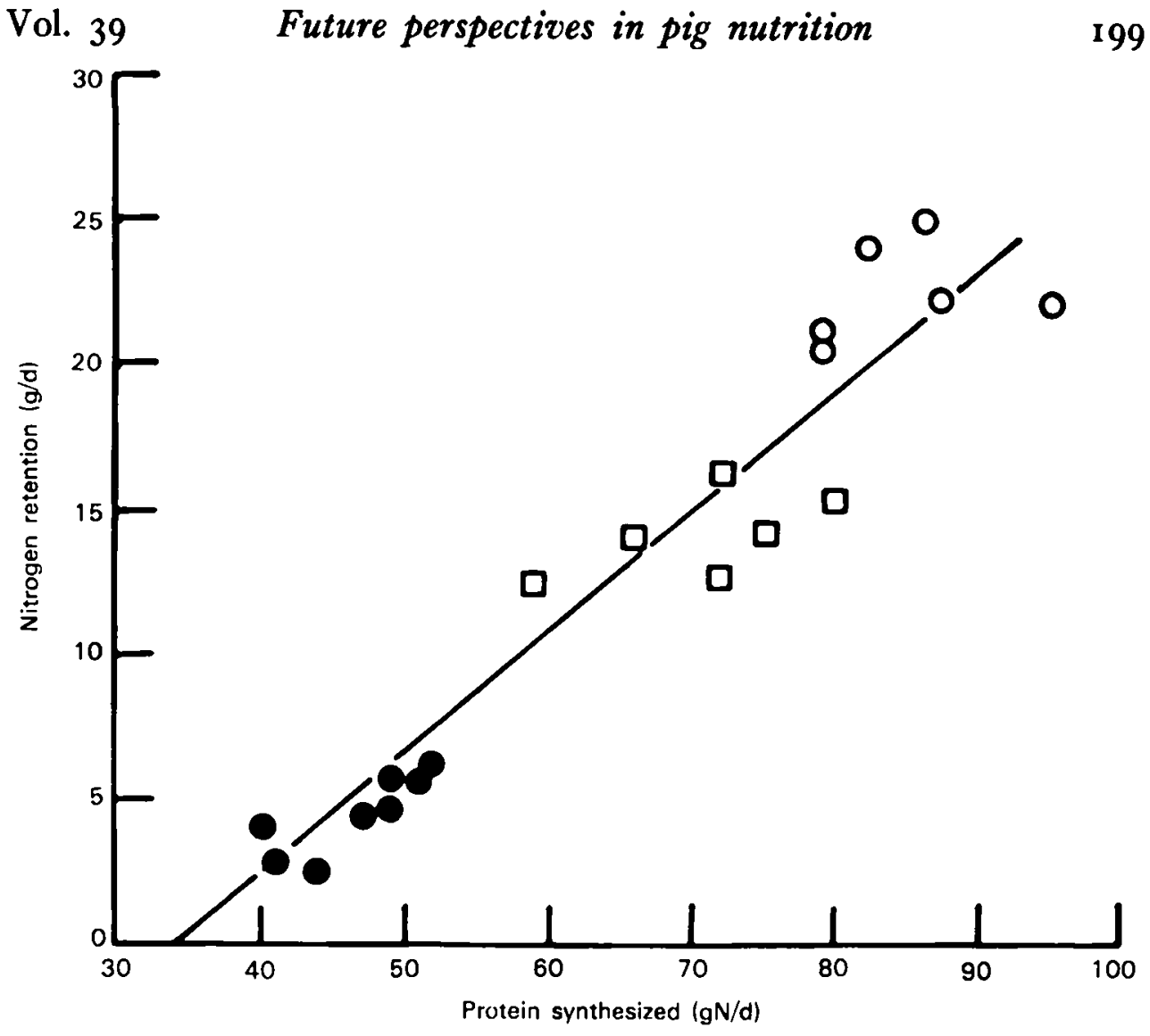

Fig. 3. The relationship between the rates of nitrogen retention and of protein synthesized in pigs of $34 \mathrm{~kg}$ given a standard diet at various rates; ( $O$ ) maintenance, ( $\square$ ) $2 \times$ maintenance, (O) $3 \times$ maintenance. Protein synthesis was estimated from the plasma flux and oxidation of $\left[{ }^{14} \mathrm{C}\right] \mathrm{L}$-leucine. The equation was $Y=0.46 x-15 \cdot 6$. The protein synthesized at $\mathrm{N}$ equilibrium was $212 \mathrm{~g} / \mathrm{d}$. (Reeds et al. 1980).

generally agreed that five is a realistic estimate. In terms of the metabolizable energy required to form these phosphate bonds, protein synthesis requires about $3.5 \mathrm{~kJ} / \mathrm{g}$.

In contrast to this, there have been numerous studies, following the model of Kielanowski (1964, 1966), in which the dietary energy associated with protein deposition has been estimated to be much greater than this; a consensus of values estimated in growing pigs (Fowler et al. I980) implies an energy expenditure of $28 \mathrm{~kJ} / \mathrm{g}$ protein deposited.

The discrepancy between these estimates, 3.5 and $28 \mathrm{~kJ} / \mathrm{g}$, has been attributed to the turnover of body protein, and this implies that in the time that $1 \mathrm{~g}$ of protein is deposited during growth, $8 \mathrm{~g}$ protein are synthesized of which $7 \mathrm{~g}$ are degraded. Measurements which Dr Reeds and I have made recently (Reeds et al. I980) suggest that there is not a proportional relationship between synthesis and deposition of protein (Fig. 3). Even on a maintenance food intake protein was synthesized by 
these $34 \mathrm{~kg}$ pigs at a rate of $250 \mathrm{~g} / \mathrm{d}$. With increasing food intake, both synthesis and accretion increase, and the regression coefficient implies that for animals fed in excess of their maintenance need, the accretion of $I \mathrm{~g}$ of protein is accompanied by the synthesis of $2.2 \mathrm{~g}$ protein and the catabolism of $\mathrm{I} \cdot 2 \mathrm{~g}$. From this, the energy cost of protein deposition would be expected to be $3.5 \times 2 \cdot 2=7 \cdot 7 \mathrm{~kJ} / \mathrm{g}$, leaving unexplained a further expenditure of $20 \mathrm{~kJ} / \mathrm{g}$. When the energy costs of maintenance and of concomitant fat deposition are added, the energy required $/ \mathrm{kg}$ protein deposited increases to $335 \mathrm{MJ}$, as in Table $\mathrm{I}$.

\section{Diet formulation}

The improvement in protein utilization that results from additions of fat or carbohydrate to a diet allow any given rate of protein deposition to be achieved by a diversity of dietary regimes (Fig. 4), by a small quantity of protein used with high efficiency through supplementation with non-protein energy, or by larger amounts of protein with less of these supplements and therefore used less efficiently. The addition of energy, as well as improving protein utilization, increases the rate of fat deposition, so that the fixed rates of protein deposition

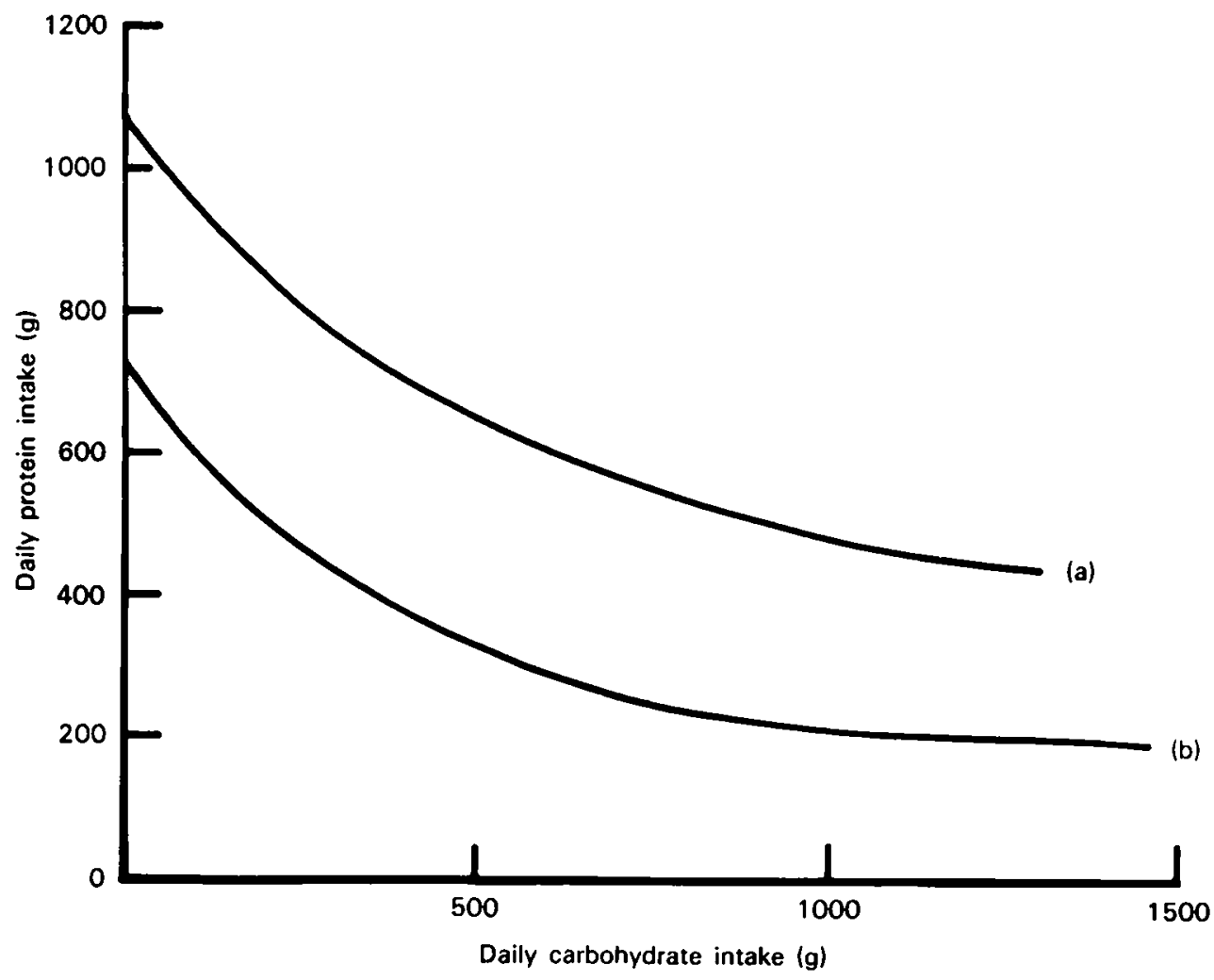

Fig. 4. Isoquants of nitrogen retention in pigs of $33 \mathrm{~kg}$ produced by simultaneous variations in the daily intakes of protein and carbohydrate. (Fuller \& Crofts, 1977). (a) $25 \mathrm{~g} / \mathrm{d}$, (b) $15 \mathrm{~g} / \mathrm{d}$. 


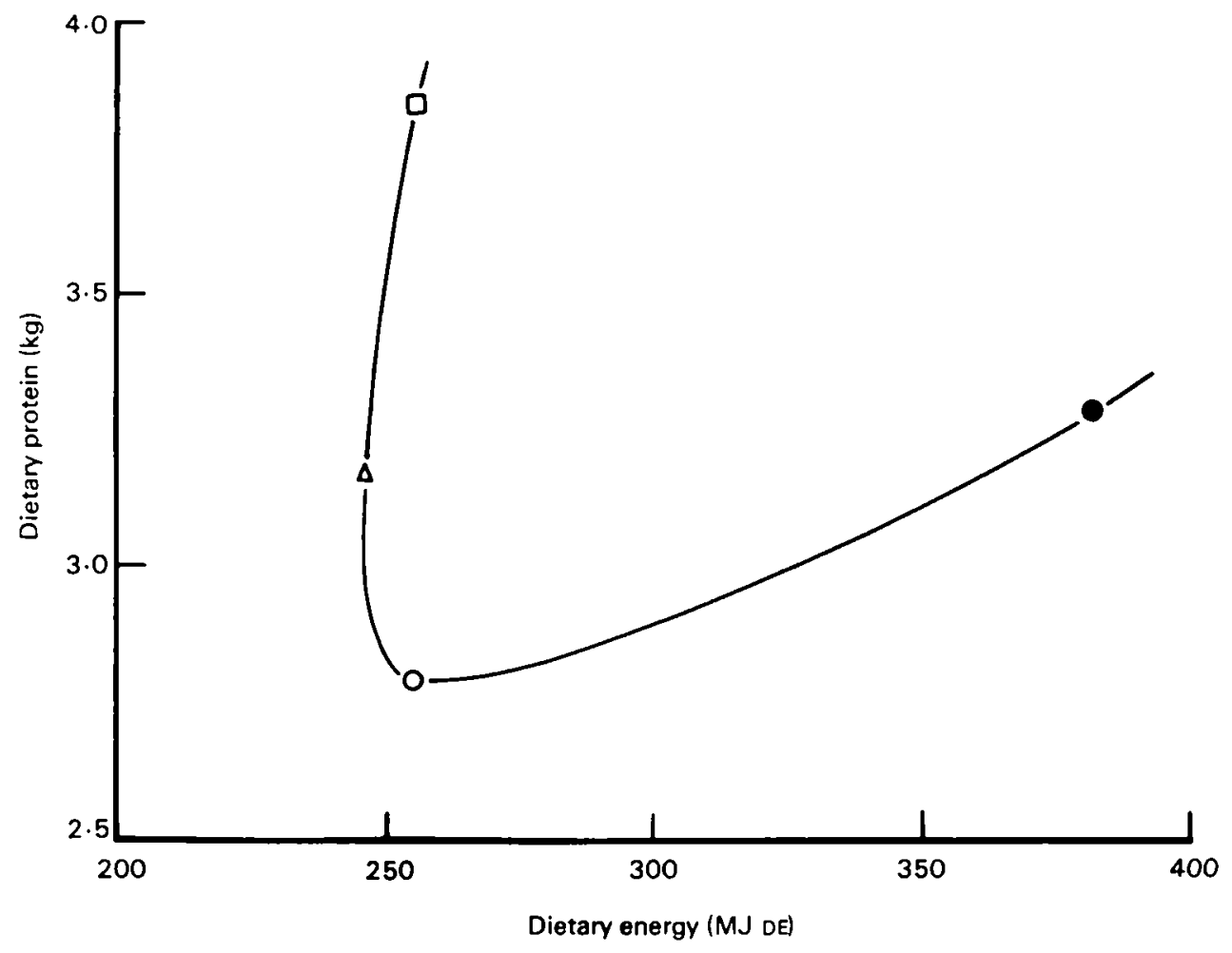

Fig. 5. The quantities of digestible energy and of protein required to produce $\mathrm{I} \mathrm{kg}$ of protein in association with $2 \mathrm{~kg}$ of lipid in pigs growing from 30 to $90 \mathrm{~kg}$. They were given diets differing in protein concentration at rates which resulted in a constant carcase specific gravity. The dietary protein concentration $(\mathrm{g} / \mathrm{kg})$ and daily feed intakes $(\mathrm{kg})$ were: $(\Theta), 104,0.98 ;(O), 132,1.87$; $(\triangle), 1_{54}, 2 \cdot 29 ;(\square), 180,3 \cdot 02$. Fuller et al. (1976a).

shown in Fig. 4 are accompanied by varying amounts of fat. To maintain a constant body composition, in terms of its fat content, requires that reductions in dietary protein concentration be accompanied by progressively severe restriction of daily food intake. This was done in the experiment shown in Fig. 5. With a diet containing only $10.4 \%$ protein the restriction required to maintain a constant protein:fat ratio was so severe that the daily maintenance requirements of both protein and energy consumed a larger fraction of intake, so that more of each was required/unit of gain.

\section{Future prospects}

In the broadest sense, future improvements in protein utilization should encompass the complete process of resource use for food production. This includes the use of improved feeds, containing better balanced proteins, and with a better balance between their protein and their carbohydrates and oils. Cereals with both more and better-quality protein, high-protein potatoes, and other roots suggest 
themselves. Because the synthesis of amino acids and protein require energy it seems inevitable that the penalty for more protein will be less yield. Conventional plant breeding may give way to cytogenetic techniques with cultured cells, as a means of identifying mutant lines with nutritionally valuable alterations of amino acid production (Fowden, 1979).

Amino acids. The industrial production of amino acids by specific fermentation seems a remarkably economical use of resources for the betterment of diets. The production of I $\mathrm{g}$ lysine, for example, requires the fermentation of only $4.5 \mathrm{~g}$ carbohydrate and for threonine $9.5 \mathrm{~g}$ (Nakayama et al. 1977). Single amino acids allow the outstanding amino acid deficiencies of staple feeds to be overcome, to meet the amino acid needs of the animal with a much lower resource cost than would be involved in producing whole proteins.

Resource recycling. Taiganides' (1979) 'Pollution is .. . Resources out of place' is a reminder that three-quarters of the faecal $\mathrm{N}$ of a pig is commonly in the form of microbial protein, nutritionally comparable to the single-cell protein produced industrially for animal feeding. Efficient use of protein might include resource recycling, either directly, or through a further stage.

Interface. The precise matching of feeds to animal needs requires better evaluation of both. We need to be able to assess what quantity of each amino acid a feed will make available to the animal, to allow in this for the interference in digestion by other substances in the feed and to predict the balance of amino acids absorbed into portal blood. We need systems of expressing nutrient requirements which take account of nutrient interactions and which define an optimum balance of amino acids appropriate to the animal's needs.

Animal protein metabolism. In considering what improvements might be made in the protein metabolism of pigs, it is helpful to distinguish those biochemical processes so intrinsic to the metabolism that they must be regarded as inevitably linked to productive processes from those that are not. The expenditure of five high-energy phosphate bonds in forming a peptide bond may be regarded as one such inevitable association; the processes which account for the remaining part of the energy cost of protein accretion may include some that are not.

In contrast, fat and protein deposition are linked by an evolved mechanism which has, in the past, best fitted its possessor for survival. Man's assumption of responsibility for his animals' survival allows the association to be broken, though the genetic variation may now be so small as to make this too an effectively inevitable association.

The key to this mechanism seems to lie in the control of amino acid oxidation by diet, especially in the mechanisms whereby increases in protein and in non-protein energy sources exert their opposing effects upon it. The ultimate limits to protein utilization are set by how much protein the pig will eat and by how rapidly it can synthesize body protein without simultaneously breaking much of it down. Better understanding of this control may allow new approaches to the selection of genetic lines which are capable of utilizing fully large amounts of balanced protein with only those quantities of carbohydrate and fat needed for the inevitable energy 
expenditures and for that small quantity of fat which consumers require to accompany their lean meat.

\section{REFERENCES}

Agricultural Research Council (1967). The Nutrient Requirements of Farm Livestock. No. 3, Pigs. London: Agricultural Research Council.

Becker, D. E., Ullrey, D. E. \& Terrill, S. W. (1954). Y. Anim. Sci. 13, 346.

Block, R. J. \& Bolling, D. (1944). F. Am. diet. Ass. 20, 69 .

Dreyer, J. J. (1975). S. Afr. med. F. 77, 1667.

Fisher, H. \& Scott, H. M. (1954). Archs Biochem. Biophys. 51, 517.

Fowden, L. (1979). Ann. rep. Scottish. Plant Breeding Stn 58, 159.

Fowler, V. R. (1976). In Meat Animals: Growth and Productivity, p. 285. [D. Lister, D. N. Rhodes, V. R. Fowler and M. F. Fuller, editors]. London: Plenum Press.

Fowler, V. R., Close, W. H., Fuller, M. F. \& Whittemore, C. T. (1980). In Energy Metabolism [L. E. Mount, editor]. (In the Press).

Fulks, R. M., Li, J. B. \& Goldberg, A. L. (1975). F. biol. Chem. 250, 290.

Fuller, M. F. \& Crofts, R. M. J. (1977). Br. $\mathscr{~}$. Nutr. 38, 479.

Fuller, M. F., English, P. R., Livingstone, R. M. \& Crofts, R. M. J. (1976a). J. agric. Sci., Camb. 86, 7 .

Fuller, M. F., Livingstone, R. M., Baird, B. A. \& Atkinson, T. (1979). Br. F. Nutr. 41, 321.

Fuller, M. F., Webster, A. J. F., MacPherson, R. M. \& Smith, J. S. (1976b). In Energy Metabolism of Farm Animals [M. Vermorel, editor]. Publs Eur. Ass. Anim. Prod. No. 19.

Houseman, R. A. (1972). PhD Thesis, University of Edinburgh.

Jefferson, L. S., Rannels, D. E., Munger, B. L. \& Morgan, H. E. (1974). Fedn Proc. Fedn Am. Socs exp. Biol. 33, 1098.

Kielanowski, J. (1964). In Energy Metabolism, p. 13. [K. L. Blaxter, editor]. Publs Eur. Ass. Anim. Prod. No. II.

Kielanowski, J. (1966). Anim. Prod. 8, 121.

Kofranyi, E. (1973). Nutr. Rep. int. 7, 45.

Large, R. V. (1973). In The Biological Efficiency of Protein Production, p. 183. [J. G. W. Jones, editor]. Cambridge: Cambridge University Press.

Large, R. V. (1976). In Meat Animals: Growth and Productivity, p. 43. [D. Lister, D. N. Rhodes, V. R. Fowler and M. F. Fuller, editors]. London: Plenum Press.

Mason, V. C. \& Palmer, R. M. (1973). Acto Agric. scand. 23, $14 \mathrm{I}$.

Mateles, R. I. (1979). In Microbial Technology: Current State, Future Prospects, p. 29. [A. T. Bull, D. C. Ellwood and C. Ratledge, editors]. Cambridge: Cambridge University Press.

Mertz, E. T., Beeson, W. M. \& Jackson, H. D. (1952). Archs Biochem. Biophys. 38, 21.

Mitchell, H. H. (1950). In Protein and Amino Acid Requirements of Mammals, p. I. [A. A. Albanese, editor]. New York: Academic Press.

Nakano, K. \& Ashida, K. (1974). Nutr. Rep. int. 10, 69.

Nakano, K. \& Ashida, K. (1975). F. Nutr. 105, 906.

Nakayama, K., Araki, K. \& Kase, H. (1977). In Nutritional Improvement of Food-Feed Proteins, p. 649. [M. Friedman, editor]. New York: Plenum Press.

Reeds, P. J., Cadenhead, A., Fuller, M. F. \& Lobley, G. E. (1980). Br. F. Nutr. (In the Press).

Rerat, A. A. \& Lougnon, J. (1968). Wld Rev. Anim. Prod. 4, 85.

Said, A. K. \& Hegsted, D. M. (1970). F. Nutr. 100, 1363.

Taiganides, P. (1979). Agricultural Wastes I, I.

Williams, H. H., Curtin, L. V., Abraham, J., Loosli, J. K. \& Maynard, L. A. (1954). f. biol. Chem. 208, 277 . 